\title{
Counter-Terrorism Measures in Selected University Campuses in Nairobi County, Kenya
}

\author{
Justus Karanja Muraya ${ }^{1}$, Emily Okuto ${ }^{2}$, Duncan Onyango Ochieng ${ }^{3}$, Noor Yarow Gabow ${ }^{4}$ \\ ${ }^{1-4}$ Africa Nazarene University
}

Kenya

\begin{abstract}
This study endeavoured to assess the security measures put in place in selected university campuses in Nairobi in response to the threat of terror. The study is pegged on the rational choice theory. A total of six University campuses and nine government departments were selected to participate in the study using random and purposive sampling techniques respectively. A total of 69 respondents were purposively selected to participate in the study. The participants were comprised of university campus directors, members of the university security management, members of the campus administration, faculty members, and various categories of student leaders. The study used the mixed-method approach and exploratory research design. Questionnaires, observation checklists, and interview guides were used to collect both qualitative and quantitative data. The Statistical Package for Social Sciences (SPSS) version 24 was used to run descriptive statistics. The inductive approach was utilised since the study accorded prominence to qualitative data. In this regard, data from interviews and open-ended questions were categorized according to the research objectives, inductively analysed, and reported in the form of narration. The responses of the principals, deans, and security personnel show that the security measures that existed in the satellite university campuses were not commensurate with or sufficient to counter the threat of a terror attack because of the many risk and vulnerability factors that were at play in each of the sampled campuses. The paper recommends that there is a need to ensure that disaster management education is standardized and introduced in all universities across the country as a compulsory examinable unit. The hiring practices of security guards for all universities need to be standardized and regulated through enforceable laws and policies. The training of security guards meant to be deployed in universities should be standardized and strictly regulated. Additionally, anyone working in a security management capacity at the university should hold a certain minimum formal education and should have served at a certain level in the disciplined forces and honourably discharged.
\end{abstract}

Key Words: Security Measures, Threat of Terror, University Campuses in Nairobi.

\section{INTRODUCTION}

The threat of terrorism in Kenya is glaring. This has negative ramifications on the education sector [1]. Indeed, the rise and rise of terrorist attacks in Kenya has led to increased concern among university administrators about the security of their facilities [2]. One of the glaring attacks against universities in Kenya was the Garissa University College terrorist attack on the $2^{\text {nd }}$ of April 2015. The attack exposed numerous weaknesses in the fight against terror attacks in institutions of higher learning. Despite this, the security measures undertaken to respond to external threats and internal vulnerability of a terror attack by the university campuses located in the City County of Nairobi are wanting [2]. In Kenya, universities are obligated by law to put in place policies aimed at ensuring that security is assured through both policy and practice. The Commission for University Education (CUE) posits that "universities to have documented policies and develop statutes, rules, and regulations" [3]. There should be strong policies aimed at instituting robust security within and in the immediate surrounding environment of university campuses through the deployment of personnel, strengthening information-sharing capabilities, and developing security infrastructure [4]. Universities in Kenya are also required to have procedures and practices that enhance their abilities to investigate and report security breaches or safety hazards by coordinating with relevant authorities. It is also obligatory to have a budget for the maintenance and management of security facilities. Additionally, universities are obligated to have enforcement mechanisms for the existing rules and elaborate security procedures [5]. Onyango points out that educational buildings are required to put in place mechanisms aimed at checking and mitigating risks of terrorism by ensuring among other things that the campus site location and layout allow for easy evacuation of the university population and deployment of response teams in the event of an attack [2]. However, some of these considerations have not been explicitly taken into consideration in some university 
campuses situated in Nairobi, which could augment vulnerabilities to security risks. This current study sets out to assess the security measures put in place in response to threats of terror in selected university campuses in Nairobi County.

\subsection{Statement of the Problem}

Most studies in the area of institutional security do not pay much attention to the security of university campuses against the threat of terror [1], [2]. Despite the threat of terror being potent and profound, only a few studies exist on the security of university campuses against the threat of terror and even those few that exist don't sufficiently address the threats, risks, and vulnerabilities of university campuses or attempted to conclusively evaluate how measures that have been put in place are robust in reducing the risk, threats and vulnerability factors or in strengthening the protective factors. This creates literature lacuna that cannot be bridged without studies in that direction.

\subsection{Purpose of the Study}

Universities respond to the threat of terrorism in various ways. This current study set out to take stock of the specific measures employed by selected university campuses in Nairobi in response to the threat of terror.

\subsection{Specific Objective}

To assess the security measures put in place in selected university campuses in Nairobi in response to the threat of terror.

\subsection{Justification}

This study would be important to security agencies and the education sector at the national and regional levels. It comes at a time when the Task Force on Security of Institutions of Higher Learning along with the State Department of University Education, and the Commission for University Education (CUE) are working on security rules and policy guidelines for universities. The Ministry of Interior and Coordination of National Government, Kenya's National Counter-Terrorism Centre (NCTC), the National Police Service (NPS), the National Disaster Management Unit (NDMU), National Disaster Operations Center (NDOC), University Senates and Faculties related to Peace, Conflict, Security and Strategic Studies, Private Security Companies and Student leaderships could find the findings of this report important when carrying out further studies in this area, and undertaking risks and vulnerability assessments and in informing satellite campuses security interventions. Also, the findings of this study could inform follow up studies on terrorism risk vulnerabilities in institutions of higher learning.

\subsection{Scope of the Study}

The study, therefore, chose only to evaluate the extent to which existing security measures in selected university campuses in Nairobi conform to national and institutional legal and policy frameworks. The study targeted two broad categories of informants; duty-bearers and right-holders within the security and education sector. Based on the concept of responsibility to protect (R2P) the category of duty-bearers comprised of university and government officials or those people who are charged with the legal mandate and have the moral duty and responsibility, and are in a position and can put in place security and safety measures to prevent the incidence of and respond to the threat of terror attack. The other category comprised of the right holders or those who are the users or consumers of these measures; the human object of the campus security measures (staff, faculty, and students). The veracity of information generated during the study was tested using information drawn from multiple sources of duty-bearers and right holders.

\subsection{Conceptual Framework}

This study conceptualizes that the security measures against the threat of terror attacks such as security and safety policies, security and safety practices, and security and safety procedures (the independent variable) determine the vulnerability of the university to terror attack (the dependent variable).

\section{LITERATURE REVIEW}

\subsection{Theoretical Framework}

The study is pegged on the rational choice theory (RCT). In the context of this study, the RCT is founded on the fundamental position that all terrorists are first and foremost human beings who have a mind that is capable of planning, executing, and evaluating the cost and benefit of an attack based on rational cognitive-mental processes [6]. As a rational being, a terrorist is capable of weighing the probability of an attack becoming successful or failed, and shaping his or her choices based on rational calculations of the risk and cost involved in a terror-operation and the veracity of security measures put in place against any attack. A terrorist will be careful to stage an attack where the evaluated probability of success is lower, benefits after a successful attack minimal, the risk of being pre-empted and apprehended high, and the cost of the operation very expensive. The one thing that is exposed by this theory is that building institutional safeguards against a terror attack will likely lower the probability of successful terror attack on a university campus, mitigate the impact of an attack, increase the risk of being detected, 
being pre-empted and attackers apprehended, and therefore make the cost of staging such an attack expensive with higher futility probability.

However, this theory makes one difficult assumption; that all human beings are endowed with similar mental and cognitive faculties with the capacity to make well-thought-out decisions and to undertake rational actions. If anything, there are many models of decision-making not all of which are based on sound rational thinking or result in sound rational actions. According to Levin and Milgram, these models take a variety of forms: some assume that people make systematic "mistakes" or optimize only partially; others assume people use fixed learning rules, or "rules of thumb" [7]. The theory fails to acknowledge people's limited and varied cognitive capacity. This according to Momanyi, therefore, means that it is crucial to carry out psychoanalysis into the psyche and mind-sets of terrorists to render studies founded on this theory valid and empirical [1]. Although the RCT provides a sound theoretical underpinning for this research, it fails to propose a theoretical approach necessary for security studies. It does not explain how terrorism becomes a security issue or provide the conceptual tools for security analysis that could have been used by this study and the satellite university campuses to carry out security and safety surveys [8]. As a result of this observation, the study made complimenting the use of the Copenhagen model of School of Security Studies (CSSS) to respond to these study concerns.

The CSSS is a school of academic thought as well as an approach to security studies which has its origins in international relations [9]. The school of thought is associated with theorist Barry Buzan's through his book "People, States, and Fear: the National Security Problem in International relations" [10]. The theory tries to move a topic away from politics and into an area of security concerns thereby legitimizing extraordinary means against the socially constructed threat such as terrorism [11]. This model was critical to this study in several ways'. Firstly, it was critical in how it emphasized the social aspects of the construction of security further expounded on in the Open Social Systems Theory (OSST); secondly, it was critical in how it explains how something becomes a security issue and; lastly one of its three conceptual tools of analysis was used to premise this study on security and education sectors and to analyse the issues of safety and security in the context of terrorism. According to Lunenburg and Ornstein, there are three major problems with contemporary approaches to security - quantity, threat variety, and threat prioritization [12]. These problems can be addressed using CSSS conceptual tools of analysis; whose security? Security of which values? And security against what? Using this theory the study was able to posit that terrorism is a security issue to universities and university campuses because of how it poses an existential threat to the object of its target; the education assets; people, infrastructure, and information. Being existential, the threat of terror attacks needs to be dealt with immediately and with extraordinary measures according to CSSS.

\subsection{Empirical Review of Literature}

Terrorism is without a doubt, one of the biggest security challenges facing the education sector in Kenya [1]. Due to increased terrorist attacks in Kenya, the university administrators and government agencies are more concerned about the security of their facilities [2]. The experience of Garissa University College terrorist attack had many lessons for universities and learning institutions globally. However, despite the lessons drawn from the Garissa University terrorist attack, the security measures taken to prevent or to respond to the external threat and internal vulnerability of a terror attack by the university campuses located in the City County of Nairobi are wanting [2]. Universities are required by law to have mechanisms including policies that cover various aspects of their functions and operations which imply that security and safety policies are a requirement in law. According to the Commission for University Education (CUE) "universities are to have documented policies and develop statutes, rules, and regulations" [5]. Universities are required to have mechanisms such as the Senate and various committees, sub-committees, and task-forces of the Senate or appointed by the Senate that oversees certain functions and operations including the security of campuses, personnel, and information [4].

Universities are therefore required to have procedures and practices including those relating to investigating and reporting the breach of security or safety hazards. They must have a budget to support the maintenance and management of security facilities and are required to have safety rules and mechanisms to ensure that the laid down rules and procedures are followed [5]. Borrowing from the State of New Jersey, university campuses can form task forces on security to identify risks, threats, and physical and cyber vulnerabilities and potential breaches of security and to make recommendations to improve school safety and security [13]. The State of New Jersey further recommended that such a task force can review measures that seek to strengthen protective factors. These measures include screening systems at university campus entrances; stationing of armed police officers within the campus premises; response times to emergencies, including lockdowns, active shooter incidents, and bomb threats; the level of technology used in student and visitor identification cards; use of biometric, retina, and other advanced recognition systems for authorized entrance into campus buildings; installation of panic alarms in school buildings to alert local law enforcement authorities to emergencies; securing computer networks to prevent cyber-attacks; scheduling periodic patrols of campus buildings, lecture halls, restaurants, parking lot, shops and grounds by local law enforcement officers; hardening the campus perimeter and building entryways; installation of Closed Circuit Television (CCTV) cameras; and increasing human surveillance from vantage points among others. 
Additionally, university campuses can review building security and assessment standards for new and existing facilities including, but not limited to, standards relating to architectural designs for buildings; identifying, assessing and controlling security threat risks and vulnerabilities in the internal and external environment of the university campus; strengthening emergency communication plans relating to security; training of students, faculty and staff; and addressing elevated risk factors such as proximity to major highways, and certain key and strategic high-risk installations and facilities including communications masts, embassies, bus parks, etc. [13]. According to Onyango, measures related to design factors to be considered in mitigating terror attacks in educational buildings include; site location and layout; land-use design, building orientation, the architectural design of buildings; structural integrity of buildings, and; mechanical and electrical systems considerations [2]. These pertain to attacks using explosive weapons. To reduce the likelihood of an attack using chemical, biological, radiological, and nuclear (CBRN) elements, security and design features of the university campus must be able to limit the terrorist's ability to approach the building and successfully release the CBRN contaminant.

Other measures recommended by Onyango include considerations related to open spaces, stand-off distance, access roads, physical protective barriers, building exterior and interior, natural surveillance, natural access control, territorial reinforcement, maintenance and management of university facilities, and crime prevention through environmental designs (CPTED) [2]. Some universities have already adopted a raft of measures including increasing the number of and use of metal detectors, profiling of students, deployment of armed police officers, and the use of CCTV among others. However, these measures are not sufficient, and in some cases aren't complemented by structured mechanisms, purposive policies, and strengthened security practices. Furthermore, the measures differ between main universities and university campuses, and from one university campus to the next alluding to lack of a common policy approach and harmonized responses implying that they could be ad-hoc or knee-jerk reactions. In the absence of security risk and vulnerability surveys -it remains to be known what informs security measures adopted by the university campuses. In some of the cases, the measures are not aligned with national laws or international best standards making these measures vulnerable to a legal challenge and unsustainable in the long run.

\section{RESEARCH METHODOLOGY}

\subsection{Research Design}

This study used exploratory research design. The design is best suited for studies on policy and practice since it is flexible and can address research questions of all types [14]. Besides, it is useful for gaining background information on a particular topic and is recommended for studies using mixed-method approaches.

\subsection{Population}

The target population for this study comprised of 20 universities with satellite campuses that are located in Nairobi City County. However, not all of them have satellite campuses within the Central Business District. On the satellite campuses, the study targeted: Campus Directors, Security Managers, and Student Leaders, Deans of students and, Deans school of humanities. The second population of interest to the study comprised of ten (10) government departments and agencies whose mandate touches on university education or security and safety in institutions of learning. As such, the study targeted 260 respondents from universities, 8 from Ministry of Interior and Coordination of National Government, 3 from Directorate of Higher Education, 5 from Departments in the NCTC and, 14 from Departments in the CUE. This makes a total population of 290 potential respondents.

\subsection{Sample}

All the 6 principals and 6 security managers of the selected university campuses were purposively selected to participate in the study as key informants, making a total of 12 university officials for face to face interviews. All seven (7) student leaders were purposively selected to participate in the study in each of the 6 university campuses -making a total of 42 student leaders. Furthermore, 6 deans were randomly selected from the sampled universities. This brings the total of study participants from the university campuses to 60. In the category of government officials, the study targeted respondents as follows; one (1) each in the Ministry of Interior, the State Department of University Education, the CUE, the NDMU, the NDOC, the National CounterTerrorism Center, the Information and Communication Technology (ICT) Authority, and two (2) from the NPS This makes a total of 9 respondents from government departments or a total sample of 69 respondents.

\subsection{Data Analysis}

The study used questionnaires, observation checklists, and interview guide to collect both qualitative and quantitative data. The questionnaires contained both open and closed-ended questions. The researcher used both qualitative and quantitative approaches to data analysis. Based on the questions, quantitative data were coded and entered for descriptive statistics computation using Statistical Package for Social Sciences (SPSS) version 24 and to run statistics such as those expressed in percentages and frequencies with the view to presenting the quantitative data in form of figures and tables for ease of presentation and interpretation. The Inductive approach was utilized since the study accorded prominence to qualitative data. Qualitative data 
were generated from interviews and questions that were open-ended, categorized into themes inductively analysed, and reported in verbatim to corroborate the findings from the questionnaire. Triangulation of data from the two major sources (duty bearers and right holders) was undertaken.

\section{FINDINGS}

\subsection{Commonly used Terrorism Prevention Measures According to Principals}

The respondents were asked to indicate a combination of any three security measures most commonly used by the university campus to prevent the incidence of a terror attack. All participants (100\%) indicated that the three most commonly used measures comprised of CCTV, Metal detectors, and private security guards. The second category of the most commonly used measures identified by half $(50 \%)$ of the participants comprised of security lighting and security alarm system. Less than a third $(25 \%)$ of the respondents indicated that armed police officers, automated access control, security vulnerability exercise, and physical barriers were commonly used to prevent the incidence of a terror attack. On the converse, all participants (100\%) indicated that there were no documented preventive measures related to policy and strategy, design, and layout of the building or training and emergency drills. Table 1 presents these findings.

Table 1: Commonly used Counter-Terrorism Measures

\begin{tabular}{|c|l|c|c|c|c|}
\hline \multirow{2}{*}{\multicolumn{2}{|c|}{ Statements }} & \multicolumn{2}{c|}{ Yes } & \multicolumn{2}{c|}{ No } \\
\cline { 3 - 6 } & & F & $(\%)$ & F & $(\%)$ \\
\hline A & CCTV Cameras & 4 & 100.0 & 0 & 0.0 \\
\hline B & Security Lighting & 2 & 50.0 & 2 & 50.0 \\
\hline C & Policy and strategy documents & 0 & 0.0 & 4 & 100.0 \\
\hline D & Metal detectors & 4 & 100.0 & 0 & 0.0 \\
\hline E & Armed police officers & 1 & 25.0 & 3 & 75.0 \\
\hline F & Automated Access Controls & 1 & 25.0 & 3 & 75.0 \\
\hline G & Building design and layout & 0 & 0.0 & 4 & 100.0 \\
\hline H & Security vulnerability assessment exercise & 1 & 25.0 & 3 & 75.0 \\
\hline I & Training and emergency drills & 0 & 0.0 & 4 & 100.0 \\
\hline J & Physical barriers & 1 & 25.0 & 3 & 75.0 \\
\hline K & Private security guards & 4 & 100.0 & 0 & 0.0 \\
\hline L & Alarm system & 2 & 50.0 & 2 & 50.0 \\
\hline
\end{tabular}

\subsection{Safety and Security Risk and Vulnerability Assessment Exercise According to Deans}

The respondents were asked to indicate if the university campus had conducted a safety and security risk and vulnerability assessment exercise in the last three years. A majority $(75 \%)$ of the respondents indicated that the satellite university campuses had not conducted any safety and security risk and vulnerability assessment exercise in the last three years while less than a third (25\%) affirmed that in the last three years the satellite university campuses had indeed conducted safety and security risk and vulnerability assessment. This is presented in Figure 1.

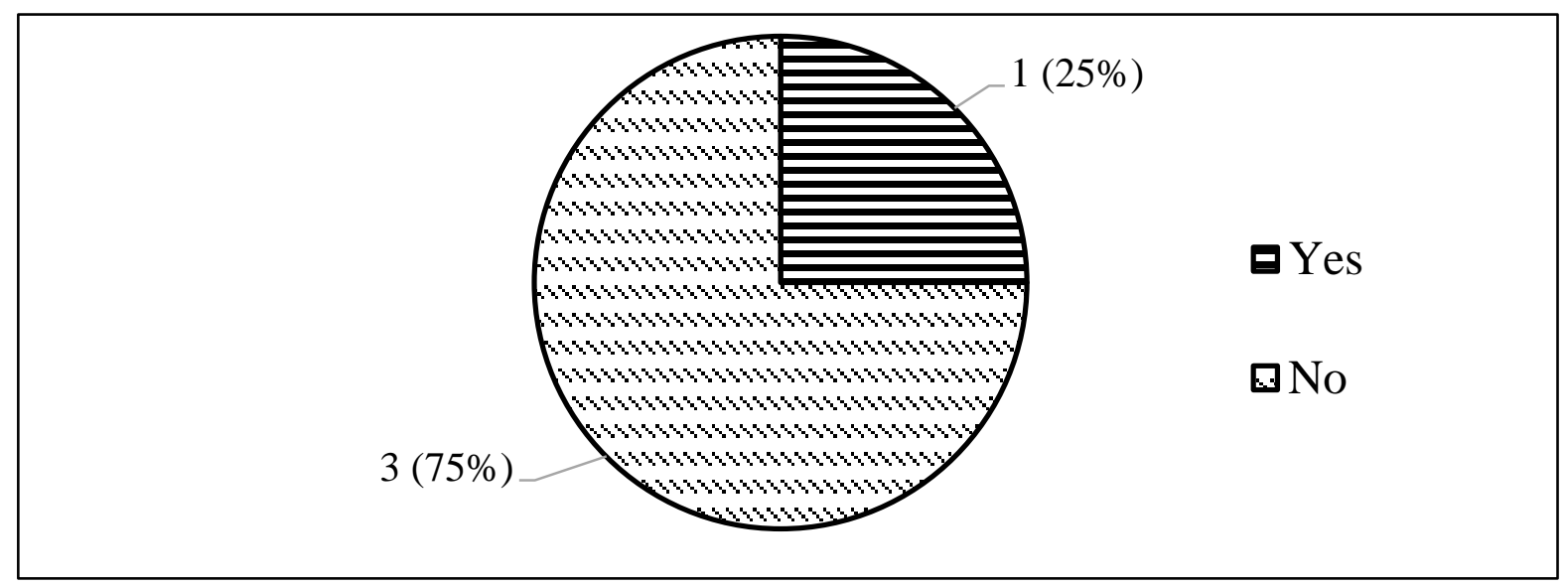

Figures 1: Security Risk and Vulnerability Assessment Exercise According to Deans 


\subsection{Security Training or Emergency Response Drills}

The respondents were asked to indicate if their respective satellite university campuses had conducted security training or emergency response drills targeting staff, faculty, and students in the last three years. All the respondents (100\%) indicated that their university campuses had not conducted security training or emergency response drills targeting staff, faculty, and students in the last three years as shown in Table 2.

Table 2: Security Training or Emergency Response Drills According to Deans

\begin{tabular}{|c|c|c|}
\hline Responses & Frequency & Percent \\
\hline Yes & 0 & 0 \\
\hline No & 4 & 100.0 \\
\hline Total & $\mathbf{4}$ & $\mathbf{1 0 0 . 0}$ \\
\hline
\end{tabular}

\subsection{Adequacy of Existing Security Measures According to Deans}

The respondents were asked to indicate if in their opinion they thought that the overall security measures put in place by the university campus were adequate to curb the threat of terror attack. A greater majority (75\%) of all the respondents indicated that the overall security measures put in place by the satellite university campus were not adequate to curb the threat of terror attacks. Only less than a third (25\%) of the respondents thought that the overall security measures put in place by the university campus were adequate to curb the threat of terror attack. These findings are presented in Figure 2.

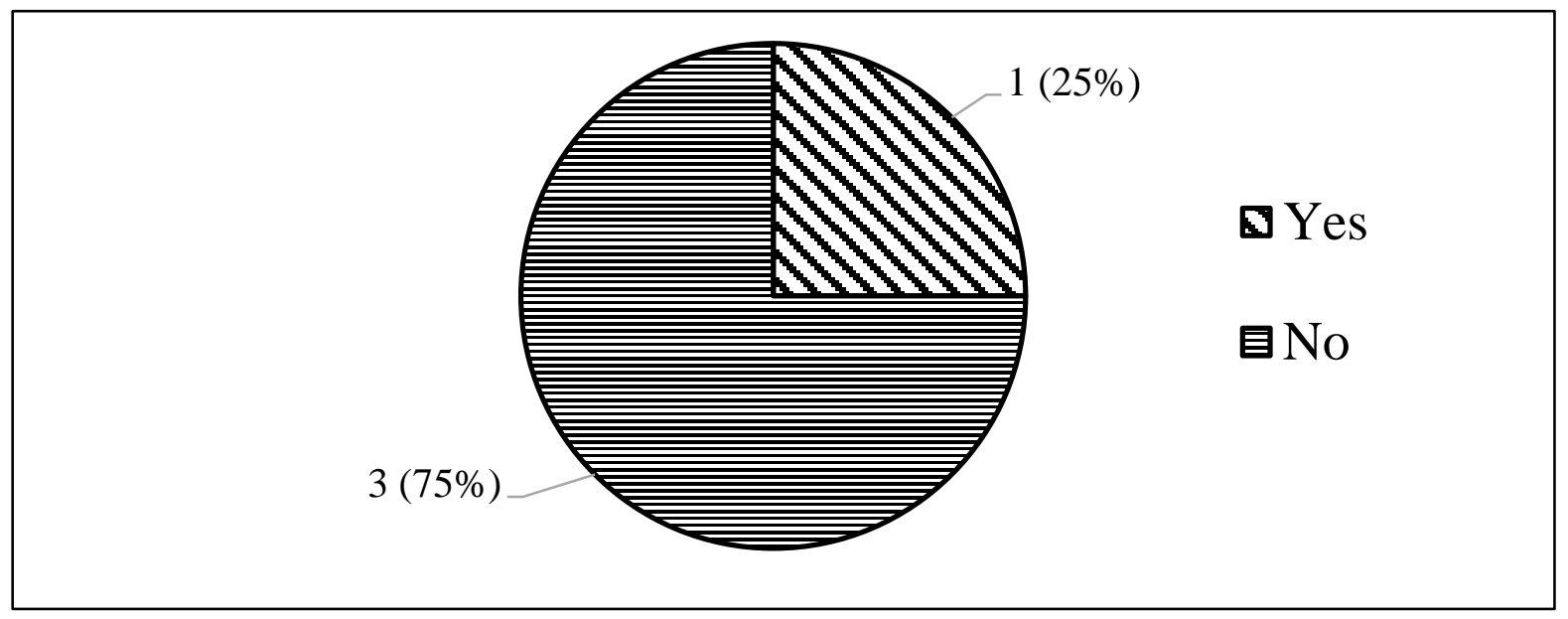

Figure 2: Adequacy of Existing Security Measures by Deans

\subsection{Self-Assessment Checklist of Security Measures by Deans}

The exercise was quantitatively responding to the objective of assessing the counter-terrorism measures put in place on university campuses in Nairobi. The quantitative self-assessment checklist comprised of 18 questions. The respondents were required to tick in the appropriate boxes indicating whether the measures described in the statement were present in their respective campuses. All (100\%) of the satellite university campuses maintain comprehensively documented students and staff profiles. They also have security information desks, have well-maintained and regularly inspected firefighting equipment, and screen visitors and issue them with a pass at the first point of entry. An overwhelming majority (83.3\%) of the satellite university campuses require all foreign students/staff to be regularized with Government in line with applicable migration laws. A significant majority (66.7\%) operate well-publicized safety and security emergency hotline number, manage a daily incident occurrence book, do some kind of background/reference check for staff and students before admission or employment, and conduct a regular physical inspection of the satellite university campus premises. Half (50\%) of the satellite university campuses maintain an updated database of security agencies' contacts in case of security-related emergencies. Slightly less than a third (33.3\%) of the satellite university campuses have students and faculty members who know what to do in case of security-related emergencies such as a terrorist attack. Additionally, only less than a third (33.3\%) have well-secured security information boxes situated in strategic points and armed police officers within the premises of the satellite university campus. An overwhelming majority $(83.3 \%)$ of the satellite university campuses don't have a well-secured safe for the storage of licensed weapons and don't allow students to come in with licensed weapons. The same number (83.3\%) don't conduct firefighting and security-related emergency response drills, and neither are their guards and security officers involved in the inspection of motor vehicles at the entrance to the 
International Journal of Advances in Scientific Research and Engineering (ijasre), Vol 6 (6), June -2020

parking area in buildings within which the satellite university campuses are situated. Only $16.7 \%$ of the satellite university campuses' have guards with special training, equipment, and capacity to deal with emergencies as presented in Table 3.

Table 3: Self-Assessment Checklist on Security Measures (Deans)

\begin{tabular}{|c|c|c|c|c|c|}
\hline \multirow{2}{*}{\multicolumn{2}{|c|}{ Statements }} & \multicolumn{2}{|c|}{ Yes } & \multicolumn{2}{|c|}{ No } \\
\hline & & $\mathbf{F}$ & $(\%)$ & $\mathbf{F}$ & $(\%)$ \\
\hline 1 & $\begin{array}{l}\text { Does the campus operate well-publicized safety and security } \\
\text { emergencies hotline number }\end{array}$ & 4 & 66.7 & 2 & 33.3 \\
\hline 2 & Does the university manage a daily incident occurrence book & 4 & 66.7 & 2 & 33.3 \\
\hline 3 & Does the campus have security information desk & 6 & 100.0 & 0 & 0.0 \\
\hline 4 & $\begin{array}{l}\text { Does the campus have well-secured security information boxes } \\
\text { situated in strategic points }\end{array}$ & 2 & 33.3 & 4 & 66.7 \\
\hline 5 & $\begin{array}{l}\text { Are students, staff, and visitors allowed to come in with licensed } \\
\text { weapons }\end{array}$ & 1 & 16.7 & 5 & 83.3 \\
\hline 6 & $\begin{array}{l}\text { Does the university have a well-secured safe for storage of licensed } \\
\text { weapons }\end{array}$ & 1 & 16.7 & 5 & 83.3 \\
\hline 7 & $\begin{array}{l}\text { Are there well maintained and regularly inspected firefighting } \\
\text { equipment at the campus }\end{array}$ & 6 & 100.0 & 0 & 0.0 \\
\hline 8 & $\begin{array}{l}\text { Does the university conduct firefighting and emergency/security } \\
\text { response drills }\end{array}$ & 1 & 16.73 & 5 & 83.3 \\
\hline 9 & $\begin{array}{l}\text { Does the university do any kind of background/reference check for } \\
\text { staff and students before admission or employment }\end{array}$ & 4 & 66.7 & 2 & 33.3 \\
\hline 10 & $\begin{array}{l}\text { Does the university require all foreign students/staff to be } \\
\text { regularized by Government }\end{array}$ & 5 & 83.3 & 1 & 16.7 \\
\hline 11 & $\begin{array}{l}\text { Are visitors to the campus screened and issued with visitors' pass at } \\
\text { the first point of entry }\end{array}$ & 6 & 100.0 & 0 & 0.0 \\
\hline 12 & $\begin{array}{l}\text { Does the university maintain updated contacts of security agencies } \\
\text { in case of emergencies }\end{array}$ & 3 & 50.0 & 3 & 50.0 \\
\hline 13 & $\begin{array}{l}\text { Do security personnel conduct regular physical inspection of } \\
\text { university premises }\end{array}$ & 4 & 66.7 & 2 & 33.3 \\
\hline 14 & $\begin{array}{l}\text { Does the university campus conduct keep comprehensively } \\
\text { documented students and staff profiles }\end{array}$ & 6 & 100.0 & 0 & 0.0 \\
\hline 15 & Does the university campus have armed police officers & 2 & 33.3 & 4 & 66.7 \\
\hline 16 & $\begin{array}{l}\text { Are vehicles to the premises where the campus is situated inspected } \\
\text { by the campus guards }\end{array}$ & 1 & 16.73 & 5 & 83.3 \\
\hline 17 & $\begin{array}{l}\text { Do the guards have any special training, equipment or capacity to } \\
\text { deal with emergencies }\end{array}$ & 1 & 16.73 & 5 & 83.3 \\
\hline 18 & $\begin{array}{l}\text { Do the students and faculty know what to do in case of a terrorist } \\
\text { attack }\end{array}$ & 2 & 33.3 & 4 & 66.7 \\
\hline
\end{tabular}

\subsection{Gender Responsive \& Disability Sensitive Evacuation plan According to Principals}

The researcher sought to find out if there existed documented gender-responsive and disability sensitive evacuation plans in the participating satellite university campuses. Only less than a third (20\%) of the satellite university campuses admitted to having such a plan. More than half $(60 \%)$ were clear that such an evacuation plan didn't exist. The remaining one university $20 \%$ was not aware of the existence of an evacuation plan. These findings are presented in Figure 3. 


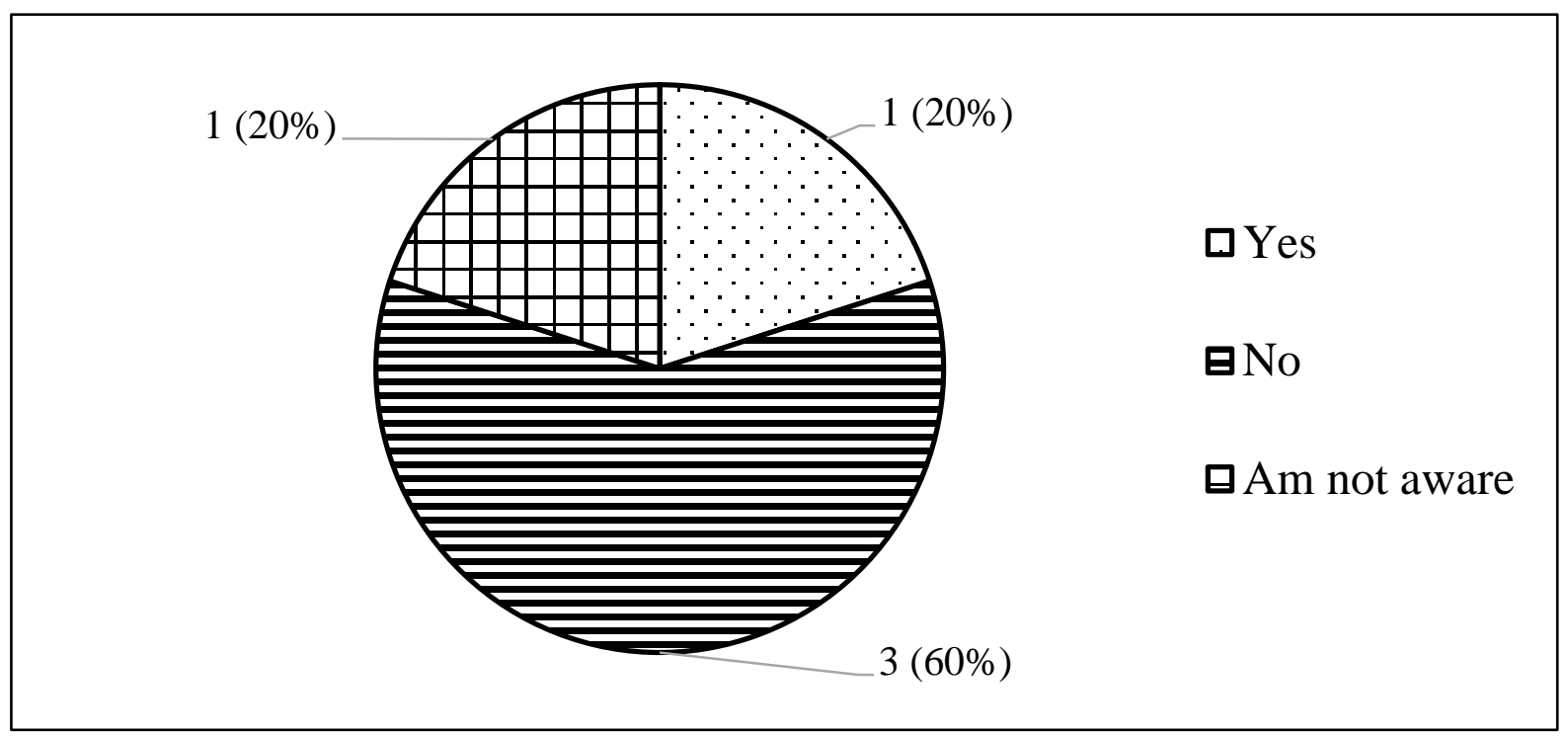

Figure 3: Gender-Responsive \& Disability Sensitive Evacuation plan According to Principals

\subsection{Gender Responsive Security Emergency Shelter According to Principals}

The study participants were requested to indicate if the satellite university campuses had a gender-responsive shelter-inplace (small well secured interior room) where staff, students, and faculty members could gather in safety and security waiting to be rescued in the event of an attack. As shown in Table 4, none of the sampled satellite university campuses had such a facility. None had ever had such a facility.

Table 4: Gender Responsive Security Emergency Shelter According to Principals

\begin{tabular}{|c|c|c|}
\hline \multirow{2}{*}{ Response } & Frequency & Percent \\
\hline Yes & 0 & 00.0 \\
\hline No & 5 & 100.0 \\
\hline Total & $\mathbf{5}$ & $\mathbf{1 0 0 . 0}$ \\
\hline
\end{tabular}

\subsection{Stakeholder Coordination Plan According to Principals}

The participants were required to indicate if the satellite university campuses had security management plans that required them to coordinate with security and disaster management sector stakeholders in planning, intelligence sharing, and joint exercises such as those meant to assess safety and security risks and vulnerability in the event of an attack. The analysis shows that over half $(60 \%)$ of the satellite university campuses had such a plan in place whereas slightly more than a third (40\%) didn't have a plan like that in place. These findings are presented in Figure 4. 


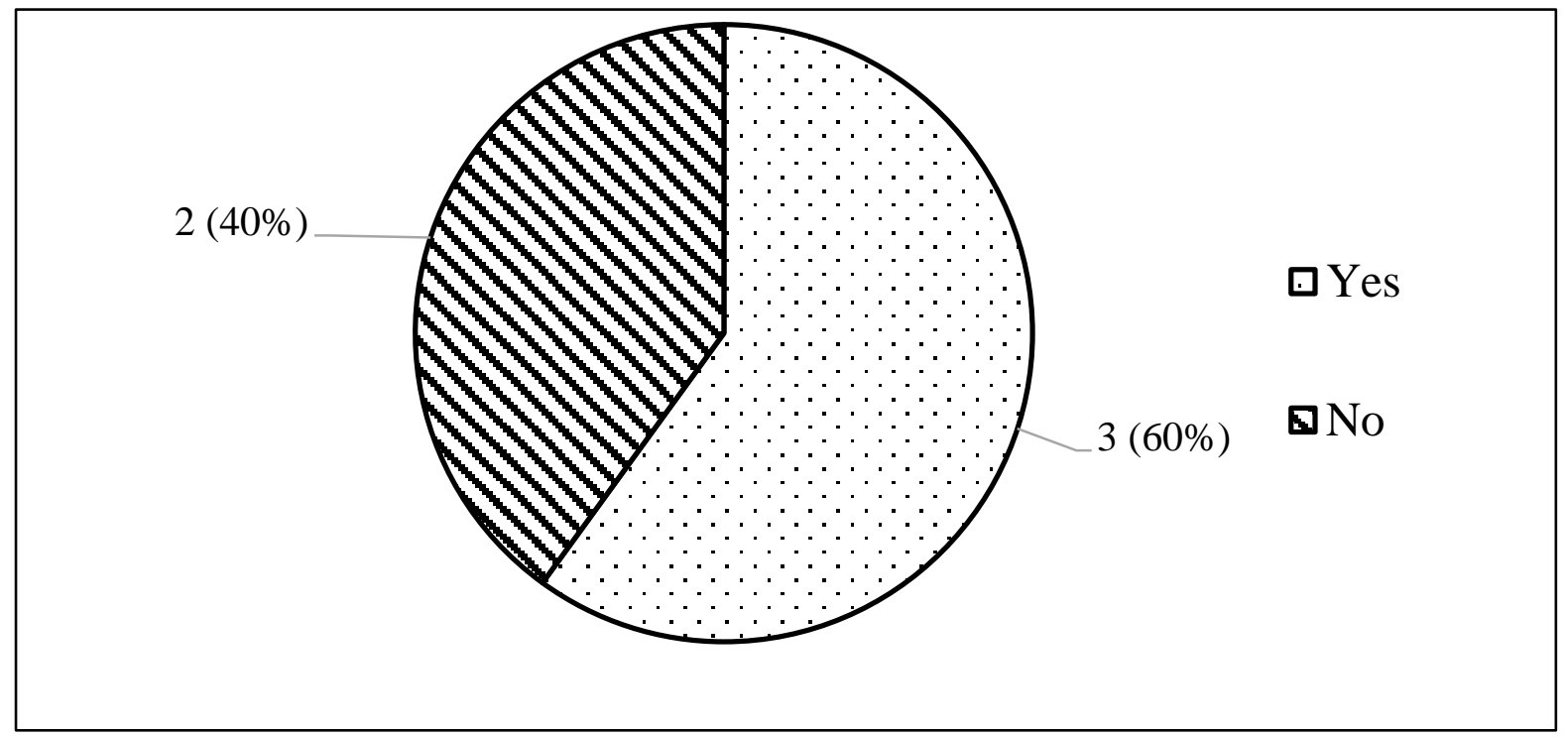

Figure 4: Stakeholder Coordination Plan According to Principals

\subsection{Effectiveness of Stakeholder Coordination Plan to Principals}

Respondents were required to rate the effectiveness of the satellite university campuses' plans in coordinating the campuses with security and disaster management sector stakeholders in planning, intelligence sharing, and joint preparedness exercises. The analysis shows that a greater majority (80\%) of the respondents didn't think that the satellite university campuses had effective coordination plans. Less than a third (20\%) thought that coordination plans in place at the satellite university campuses were effective in coordinating with security and disaster management sector stakeholders, and would kick in well in the event of an attack as shown in Figure 5.

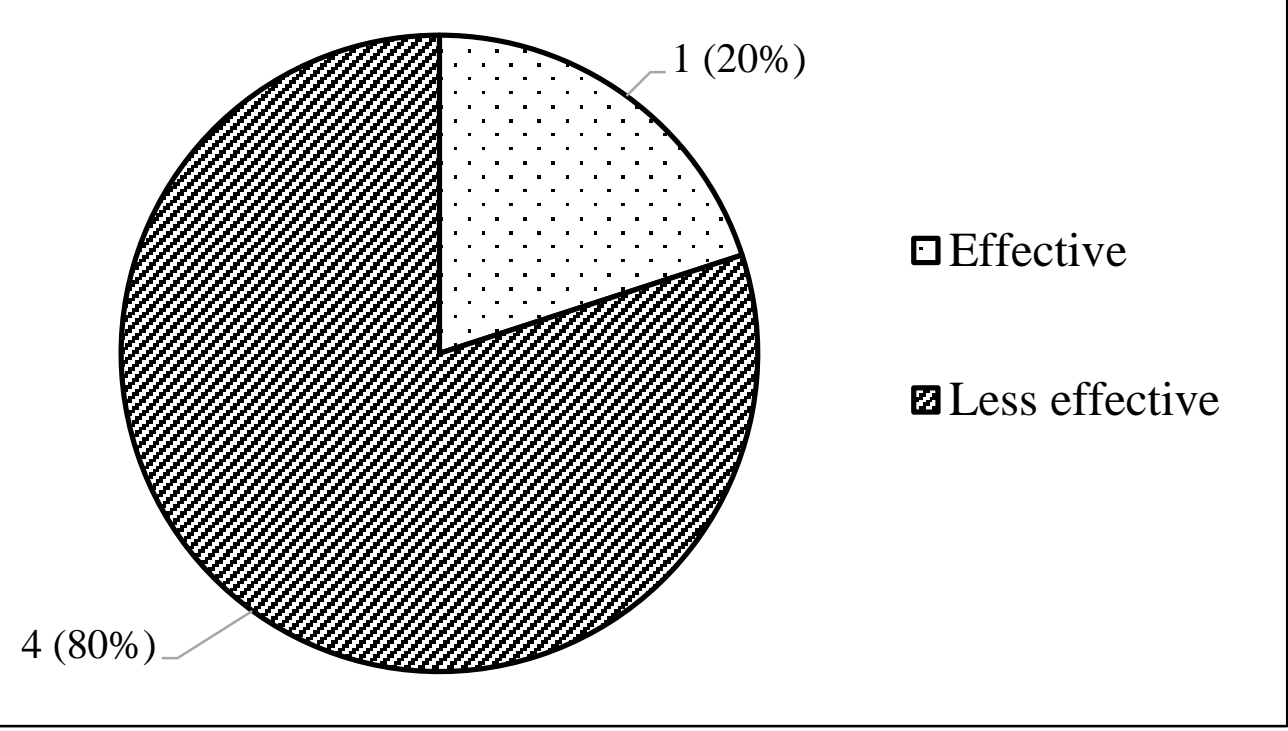

Figure 5: Effectiveness of Stakeholder Coordination Plan to Principals

\subsection{Counter-Terrorism Measures Put in Place in University Campuses in Nairobi According to Principals}

On the question of what security measures the satellite university campuses had deployed to address the risks and vulnerability of terrorist attacks, the respondents mentioned measures related to equipment, systems, practices, and procedures as recommended by Atta-Asamoah [15]. When asked if these measures were sufficient to prevent, mitigate and respond to the threat and incidence of a terrorist attack on university assets, the respondents reported that considering the threat of a sophisticated terrorist attack, the measures in place at the satellite university campuses can't be said to be sufficient or commensurate with the high-risk assets that the campuses possessed.

They disclosed that universities didn't have a way of differentiating between high profile students and ordinary ones. However, they admitted that there are categories of high profile students who may require additional security measures at the satellite university campus since they could be premium targets for terror attacks. 
When asked to state the measures put in place by the satellite university campuses to protect the very important and strategic human assets against the threat of poisoning, shooting, abduction, hostage-taking, assassinations or other forms of terrorist attack, the respondents expressed that there were no special measures that satellite university campuses had deployed to protect important and strategic human assets as recommended by the Ministry of Education (MOE) [16].

Regarding the measures put in place by the satellite university campuses to protect the property of the university campuses against intrusion, loss, damage or destruction in the event of a terrorist attack or to safeguard and make this category of assets less attractive to adversaries, the respondents mentioned that they had contracted or hired private security guards. In very rare cases, such as those involving direct threats or special occasions do the universities deploy armed police officers.

When asked if the security guards had counter-terrorism training or any special skills and equipment to aid them in managing physical risks and vulnerability related to the threat of terrorist attacks, the respondents said that the guards didn't have any special training, skills or equipment as recommended by Atta-Asamoah [15]. The majority of them are ordinary secondary school leavers, and there has not been policy emphasis that such guards should have served in the security forces.

On the question of what the major challenges in enforcing the security measures are, the respondents explained that training, skills, equipment, motivation, and the general working condition of the private security guards was a huge challenge. According to one of the respondents;

"We noticed that the private security guards are often hurriedly trained, inadequately briefed, inappropriately deployed, poorly coordinated, exploited, and harassed by the security firms that hire and manage them. The burden of managing a poorly paid, overworked disgruntled, disillusioned, and demotivated security guard becomes our own. This has the potential of exposing the university to security lapses and risks. As a result of painful lessons learned-we embarked on the process of hiring our guards, training them, equipping them and managing them through the university security and safety department which is managed by officers with a security background."

When asked if the students undergo any disaster education or security emergency training, orientation, and drills, the respondents had varied answers. All the answers appeared to point to the fact that there were hardly any structured security emergency training, orientation, and drills in the university campuses. However, some universities organize occasional talks, workshops, or security orientation for first-year students. These activities are not mandatory or part of the university curriculum, and therefore faculty members and students are at liberty not to attend and therefore hardly realize the intended outcome in terms of coverage. Additionally, these measures don't involve security experts and practitioners outsourced from specialized security agencies, and they are not well designed to respond to the threat of terror attacks in terms of prevention, preparedness, mitigation, response, and recovery.

Regarding the security procedures and practices, the respondents observed that there were elaborate security procedures and practices that involved various elements such as displaying identification cards, body search, and inspection of luggage and, use of metal detectors among others. However, these are not strictly enforced by the security guards. Also, there is neither strict compliance by faculty and students nor strict monitoring by the university administration.

When asked if the management of the buildings in which satellite university campuses were located had put in place sufficient security measures to ensure that the campuses were safe, the respondents agreed that whatever measures were in place were no adequate and a lot still required to be done. For instance, some of the buildings neither had functional fire detection and fighting equipment, nor emergency exists, nor designated fire assembly points, nor emergency alarm services, among others as recommended by Odhiambo, Wasike, and Kimokoti [17].

To quote one of the respondents,

"Even if the university campuses would like to conduct a fire-fighting drill what equipment would they use during the drill? That explains why these drills are not popular with universities. Besides, even those few that have attempted to conduct these drills -they only do it as a matter of good practice but not as a matter of policy requirement."

On the question of whether there is coordination between the satellite university campuses and security agencies, the respondents observed that there were very little coordination and communication efforts between the satellite university campuses and the national security apparatus, including those under which the satellite university campuses fall. To quote one respondent,

"I guess they innocently expect such coordination to be initiated and managed by their mother institutions, some of which are located in different counties."

Another respondent affirming the same point but from a different perspective explained thus,

"We have to remind ourselves that there are university campuses in this County that fall within our area of administrative and security jurisdiction -that we are required to protect. Otherwise, they will not come to us unless we go to them."

These statements were further confirmed by a respondent from one of the sampled universities, 
"There was a time we detained an outsider who was peddling illegal drugs on the campus -none of us at the university had any contacts of Central police station. We had to ask around among students taking security-related courses to help us out with the contacts".

When asked what technological and system measures had been adopted by the satellite university campuses, the researcher observed that only an overwhelming majority of the university campuses were using CCTV cameras, and metal detectors. Some respondents explained that they were required under the new government regulations to adopt the use of biometric systems -but were in the process of replacing the old student identification systems to comply with the requirements from the Commission for University Education.

\section{CONCLUSION}

The responses of the principals, deans, and security personnel show that the security measures that existed in the satellite university campuses were not commensurate with or sufficient to counter the threat of a terror attack because of the many risk and vulnerability factors that were at play in each of the sampled campuses.

\section{RECOMMENDATIONS}

The study recommends that there is need to ensure that disaster management education is standardized and introduced in all universities across the country as a compulsory examinable unit. This will ensure that issues of safety and security because of terror attacks or any other security and safety-related disaster are accorded the seriousness they deserve. The hiring practices of security guards for all universities need to be standardized and regulated through enforceable laws and policies. It should be made a legal requirement that all private security guards and their contracting companies undergo security vetting. The training of security guards meant to be deployed in universities should be standardized and strictly regulated. Additionally, anyone working in a security management capacity at the university should hold a certain minimum formal education and should have served at a certain level in the disciplined forces and honourably discharged. There is need for a joint-task force domiciled at the Commission for University Education that comprises of actors from the NDMU, NDOC, Ministry of Interior, Public Health Department, Directorate of University Education, CUE, National Construction Authority (NCA), County Government, National Environmental Management Authority (NEMA), and the government ministry related to planning and public works. There should also be a representation of students and faculty. County Security Committees should be restructured to have the thematic focus on the security of learning institutions. A Sub-Committee of the County Security Committee can be dedicated to the security and safety of learning institutions and allowed to co-opt a few experts and stakeholders from the education sector. This Sub-Committee should have the powers, human, technical, and financial support to conduct compulsory security and safety audits on all satellite university campuses within their Counties. University academic departments related to security studies should be strengthened and empowered more to provide technical and advisory support to the security management of the satellite campuses. Satellite campuses need to utilize expert resources within the student population and faculty.

\section{REFERENCES}

[1]. Momanyi, S. (2015). The Impact of Al-Shabaab Terrorist Attacks in Kenya. Master's Thesis. The Arctic University of Norway.

[2]. Onyango W.F (2012). Assessment of Terror Disaster Preparedness and Mitigation in the University of Nairobi, Main Campus. Masters' Thesis. University of Nairobi.

[3]. Commission for University Education, CUE. (2016). Recognized university campuses in Kenya. Government of Kenya.

[4]. UWS. (2017). University Senate Committees 2017/2018. University of the West of Scotland.

[5]. Commission for University Education, (CUE). (2014). Universities Standards \& Guidelines. Government of Kenya.

[6]. Heath-Kelly, K. (2012). Counter-Terrorism and the Counterfactual: Producing the Radicalisation' Discourse and the UK PREVENT Strategy. Critical Studies on Terrorism, 5 (1), 69-87.

[7]. Levin, J., \& Milgrom, P. (2004). Introduction to Choice Theory. Retrieved on July 1, 2018, from http://www.stanford.edu/ jdlevin/Econ\%20202/Choice\%20Theory.pdf.

[8]. Lukas, L. (2015). “On theory of security”. In: Kosicka bezpecnostna, revue, 2 (1), 187 -192.

[9]. Hynek, N., \& Chander, D., (2013), No emancipatory alternative, no critical security studies, Critical Studies on Security. Critical Studies on Security, 1 (1), 46-63.

[10]. Buzan, B. (1983). People. States \& Fear: An Agenda for International Security Studies in the post-Cold War Era. Colchester: ECPR Press.

[11]. Corry, O. (2010). "Securitization and 'Riskization': Two Grammars of Security; Working paper prepared for Standing Group on International Relations.” 7th Pan-European International Relations Conference, 9-11 September, Stockholm. 
International Journal of Advances in Scientific Research and Engineering (ijasre), Vol 6 (6), June -2020

[12]. Lunenburg, F. C., \& Ornstein, A. O. (2008). Educational administration: Concepts and practices (5th Ed.). Belmont, CA: Wadsworth/Cengage Learning.

[13]. State of New Jersey (2015). New Jersey Schools Security Task Force Report \& Recommendations. The United States of America.

[14]. Burns, S. \& Grove, K. (2015). Strategic Management of Human Resources in Construction. Journal of Management in Engineering, 20(2), 78-89.

[15]. Atta-Asamoah, A. (2015). Responses to insecurity in Kenya: Too much, too little, too late. East Africa Report, (3), 1.

[16]. Ministry of Education (2008). Safety Standards Manual for Schools in Kenya. Church World

[17]. Odhiambo, E. Wasike, S. \& Kimokoti, S. (2015). Learning Institutions' Vulnerability to Terrorism. An Overview of Issue Coverage in Nowadays' Media and Specialized Literature \& A Case Study of Garissa University College, Kenya. Journal of Defense Resource Management, 6 (2), 11. 